\title{
Projected climate change under different scenarios in central region of Punjab, India
}

\section{NAVNEET KAUR and PRABHJYOT-KAUR}

\author{
School of Climate Change and Agricultural Meteorology, \\ Punjab Agricultural University, Ludhiana-141004 \\ Email :prabhksidhu@gmail.com
}

\begin{abstract}
The regional climate model viz. PRECIS(Providing Regional Climates for Impact Studies) model was used to downscale the future climatic data for the central region of Punjab, India.The projected data for the $21^{\text {st }}$ century under different scenarios was corrected by using the climate data recorded for the 1971-1990 at meteorological station of Punjab Agricultural University, Ludhiana (Central Region of Punjab) and baseline data derived from PRECIS model. The corrected data was then analyzed on annual, seasonal and monthly basis to quantify the changes in maximum and minimum temperature and rainfall. The projected data showed increase inmaximum and minimum temperature where as an irregular trend in rainfall was observed.It was projected that maximum and minimum temperature and rainfall would increase linearly under the A1B scenario for the mid century. At the end of the century, the rise in maximum and minimum temperature in $B 2$ scenario will continue but at slower rate than the $A 1 B$ and $A 2$ scenarios. There would be deficit of rainfall by 78 and $30 \%$ during the winter season under the A2 and B2 scenarios of the end century.
\end{abstract}

Keyword: Climate change, PRECIS model, A1B scenario, A2 scenario and B2 scenario

Over the last century, earth has experienced changes in climate due to increase in temperature and $\mathrm{CO}_{2}$ concentration as a result of anthropogenic factors including changes in land use pattern (Islam and Sikka, 2010) and emission of green house gases (GHG) from industrial as well as agriculture sector (Rozenweig and Hillel, 1998). The increased GHGs concentration in lower atmosphere of the earth is likely to determine earth's average temperature or warming, influence precipitation and storm patterns as well as raising in the sea levels (IPCC 2007; Dash and Hunt 2007; Rajendran and Kitoh, 2008). The global warming potential (GWP) of various GHG's, i.e., of $\mathrm{CO}_{2}, \mathrm{CH}_{4}$ and $\mathrm{N}_{2} \mathrm{O}$ is 1,21 and 310, respectively (Recosky et al,2000). The visible footprints of these changes i.e. the increase in frequency of occurrence of extreme events (heat / cold wave, flood, drought etc.) have already been observed (Meehl et al, 2007).

Throughout the $21^{\text {st }}$ century, India is projected to experience warming above the global mean (Rupakumar et $a l, 2006)$. There are projections that global $\mathrm{CO}_{2}$ and temperature levels are going to increase under various scenarios of climate change (McCarthy et al, 2001). In India an increase in annual mean and maximum temperatures by about 0.7 and $0.8{ }^{\circ} \mathrm{C}$, respectively has been reported by Dash et al (2007). A warming trend has been observed along the west coast, in central India, the interior peninsula and Northeast India. Region wise analysis of temperature in India (Islam and Sikka, 2010) showed a maximum increase in maximum temperature in the west coast (by $1.2^{\circ} \mathrm{C}$ ), followed by north-east (by $1.0^{\circ} \mathrm{C}$ ), western Himalayas (by $0.9^{\circ} \mathrm{C}$ ), north central (by $0.6^{\circ} \mathrm{C}$ ), north-west (by $0.6^{\circ} \mathrm{C}$ ), east coast (by $0.6{ }^{\circ} \mathrm{C}$ ) and interior peninsula (by $0.5^{\circ} \mathrm{C}$ ).

The region to region variation in climate is driven by the uneven distribution of solar heating, the individual responses of the atmosphere, oceans and land surface, the interactions between these, and the physical characteristics of the regions (Christensen et al, 2007). Increasingly reliable regional climate change projections are now available for many regions of the world due to advances in modeling and understanding of the physical processes of the climate system.

Keeping these different scenarios in mind, the results of the regional climate simulation model i.e. PRECIS (Providing Regional Climate for Impact Studies) have been presented in this paper under different scenarios (A1B, A2 and B2) for the mid and end of $21^{\text {st }}$ century.

\section{MATERIALS AND METHODS}

The baseline (1961-1990) and projected (2021-2100) meteorological data for central region of the Punjab i.e. 
Table 1: Changes in maximum temperature $\left({ }^{\circ} \mathrm{C}\right)$ for the mid and end century for different scenarios and their deviation from baseline period

\begin{tabular}{|c|c|c|c|c|c|}
\hline \multirow[t]{2}{*}{$\begin{array}{l}\text { Month/ } \\
\text { Season }\end{array}$} & \multirow[t]{2}{*}{$\begin{array}{c}\text { Baseline } \\
(1971-1990)\end{array}$} & \multirow{2}{*}{$\begin{array}{c}\text { Mid century } \\
(2021-2050) \\
\text { A1B }\end{array}$} & \multicolumn{3}{|c|}{$\begin{array}{l}\text { End century } \\
(2071-2100)\end{array}$} \\
\hline & & & A1B & $\mathrm{A} 2$ & B2 \\
\hline January & 18.7 & $18.3(-0.4)^{*}$ & $21.3(+2.6)$ & $23.2(+4.5)$ & $20.1(+1.4)$ \\
\hline February & 20.9 & $27.6(+6.7)$ & $31.3(+10.4)$ & $33.5(+12.6)$ & $30.4(+9.5)$ \\
\hline March & 26.1 & $41.6(+15.5)$ & $43.7(+17.6)$ & $46.4(+20.3)$ & $43.3(+17.2)$ \\
\hline April & 34.4 & $48.1(+13.7)$ & $50.8(+16.4)$ & $52.5(+18.1)$ & $50.4(+16.0)$ \\
\hline May & 38.6 & $54.5(+15.9)$ & $57.4(+18.8)$ & $55.6(+17.0)$ & $54.0(+15.4)$ \\
\hline June & 38.6 & $47.8(+9.2)$ & $49.6(+11.0)$ & $44.4(+5.8)$ & $43.3(+4.7)$ \\
\hline July & 34.4 & $33.8(-0.6)$ & $36.2(+1.8)$ & $34.7(+0.3)$ & $33.6(-0.8)$ \\
\hline August & 33.4 & $31.6(-1.8)$ & $34.6(+1.2)$ & $34.1(+0.7)$ & $33.1(-0.3)$ \\
\hline September & 33.6 & $31.2(-2.4)$ & $34.7(+1.1)$ & $32.4(-1.2)$ & $30.3(-3.3)$ \\
\hline October & 31.9 & $24.9(-7.0)$ & $29.7(-2.2)$ & $26.5(-5.4)$ & $24.0(-7.9)$ \\
\hline November & 26.5 & $18.1(-8.4)$ & $20.6(-5.9)$ & $19.9(-6.6)$ & $16.5(-10.0)$ \\
\hline December & 20.6 & $15.0(-5.6)$ & $17.6(-3.0)$ & $19.0(-1.6)$ & $16.1(-4.5)$ \\
\hline Kharif & 35.1 & $37.3(+2.2)$ & $40.4(+5.3)$ & $38.0(+2.9)$ & $36.4(+1.3)$ \\
\hline$R a b i$ & 24.5 & $28.0(+3.5)$ & $30.9(+6.4)$ & $32.4(+7.9)$ & $29.3(+4.8)$ \\
\hline Annual & 29.8 & $32.7(+2.9)^{*}$ & $35.6(+5.8)$ & $35.2(+5.4)$ & $32.9(+3.1)$ \\
\hline
\end{tabular}

* Figures in parenthesis indicate the change in ${ }^{\circ} \mathrm{C}$ temperature from the baseline period

Ludhiana was downscaled using PRECIS (Providing Regional Climates for Impact Studies) model prepared by IITM, Pune. Ludhiana is situated at $30^{\circ} 54^{\prime}$ N latitude and $75^{\circ} 56^{\prime}$ E longitude and $247 \mathrm{~m}$ above mean sea level. The daily data for maximum temperature, minimum temperature and rainfall for the baseline period (1961-1990) and projected data for A1B scenario for mid century (20212050) and for A1B, A2 and B2 scenarios for the end of

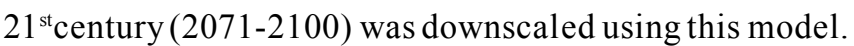
Thereafter correction factor was derived from the daily simulated data (1971-1990) and actual meteorological data (1971-1990) and further the projected weather data for the mid and end century was corrected by applying correction factor.

Then the corrected weather data was analyzed on annual,kharif season, rabi season and monthly basis to quantify the changes in maximum temperature $\left({ }^{\circ} \mathrm{C}\right)$, minimum temperature $\left({ }^{\circ} \mathrm{C}\right)$ and rainfall $(\mathrm{mm})$ from the baseline period. The annual maximum and minimum temperature and rainfall data were further regressed to quantify the rate of increase / decrease in the temperature and rainfall during the mid and upto the end of $21^{\text {st }}$ century under different scenarios of climate change.

\section{RESULTS AND DISCUSSION}

\section{Changes in maximum temperature}

The differences in maximum temperature, minimum temperature and rainfall from their baseline during the mid (2021-2050) andend (2071-2100) of $21^{\text {st }}$ century under different scenarios as predicted by the PRECIS-model, averaged over the central region of Punjab are given in Table 1.

The projections indicate that annual maximum temperature will increase by $2.9^{\circ} \mathrm{C}$ during the mid century. Also, a warming trend will be observed towards the end of century (2071-2100) under different scenarios. At the end of century, annual maximum temperature will be higher by 5.8 , $5.4^{\circ} \mathrm{C}$ and $3.1^{\circ} \mathrm{C}$ in the $\mathrm{A} 1 \mathrm{~B}, \mathrm{~A} 2$ and $\mathrm{B} 2$ scenario as compared to the baseline period $\left(29.8{ }^{\circ} \mathrm{C}\right)$. Increase in maximum temperature will be higher for the rabi season as compared to the kharif season. The rate of increase would also vary with the time of century. For example, at A1B of mid of century, A1B, A2 and B2 scenarios of the end century, the increase in maximum temperature would be 2.2, 5.3, 2.9 and $1.3^{\circ} \mathrm{C}$, respectivelyfrom baseline maximum temperature of $35.1{ }^{\circ} \mathrm{C}$ during kharif season; and 3.5, 6.4, 7.9 and $4.8^{\circ} \mathrm{C}$, respectively from baseline maximum temperature of $24.5^{\circ} \mathrm{C}$ during the rabi season. 
Table 2 : Changes in minimum temperature $\left({ }^{\circ} \mathrm{C}\right)$ for the mid and end century for different scenarios and their deviation from baseline period

\begin{tabular}{|c|c|c|c|c|c|}
\hline \multirow[t]{2}{*}{$\begin{array}{l}\text { Month/ } \\
\text { Season }\end{array}$} & \multirow[t]{2}{*}{$\begin{array}{c}\text { Baseline } \\
(1971-1990)\end{array}$} & \multirow{2}{*}{$\begin{array}{c}\text { Mid century } \\
(2021-2050) \\
\text { A1B }\end{array}$} & \multicolumn{3}{|c|}{$\begin{array}{l}\text { End century } \\
(2071-2100)\end{array}$} \\
\hline & & & A1B & $\mathrm{A} 2$ & $\mathrm{~B} 2$ \\
\hline January & 5.2 & $1.2(-4.0)^{*}$ & $3.2(-2.0)$ & $2.3(-2.9)$ & $0.7(-4.5)$ \\
\hline February & 6.9 & $6.6(-0.3)$ & $10.2(+3.3)$ & $10.4(+3.5)$ & $8.3(+1.4)$ \\
\hline March & 11.1 & $18.3(+7.2)$ & $20.9(+9.8)$ & $22.3(+11.2)$ & $19.8(+8.7)$ \\
\hline April & 16.8 & $27.3(+10.5)$ & $30.0(+13.2)$ & $30.9(+14.1)$ & $29.6(+12.8)$ \\
\hline May & 21.8 & $36.1(+14.4)$ & $39.5(+17.8)$ & $39.4(+17.7)$ & $36.8(+15.1)$ \\
\hline June & 25.3 & $36.6(+11.3)$ & $39.0(+13.7)$ & $35.9(+10.6)$ & $34.8(+9.5)$ \\
\hline July & 25.6 & $29.4(+3.8)$ & $31.2(+5.6)$ & $30.5(+4.9)$ & $29.6(+4.0)$ \\
\hline August & 25.0 & $28.8(+3.8)$ & $30.9(+5.9)$ & $30.3(+5.3)$ & $29.4(+4.4)$ \\
\hline September & 22.2 & $28.1(+6.0)$ & $31.0(+8.9)$ & $30.1(+8.0)$ & $28.8(+6.7)$ \\
\hline October & 16.0 & $21.0(+5.1)$ & $24.9(+9.0)$ & $23.4(+7.5)$ & $22.1(+6.2)$ \\
\hline November & 10.0 & $12.8(+2.8)$ & $14.8(+4.8)$ & $11.2(+1.2)$ & $10.1(+0.1)$ \\
\hline December & 6.0 & $3.2(-2.8)$ & $5.2(-0.8)$ & $3.1(-2.9)$ & $1.7(-4.3)$ \\
\hline Kharif & 22.6 & $30.0(+7.4)$ & $32.7(+10.1)$ & $31.6(+9.0)$ & $30.2(+7.6)$ \\
\hline$R a b i$ & 9.3 & $11.6(+2.3)$ & $14.0(+4.7)$ & $13.4(+4.1)$ & $11.6(+2.3)$ \\
\hline Annual & 16.0 & $20.9(+4.9)^{*}$ & $23.4(+7.4)$ & $22.5(+6.5)$ & $21.0(+5.0)$ \\
\hline
\end{tabular}

* Figures in parenthesis indicate the change in ${ }^{\circ} \mathrm{C}$ temperature from the baseline period

Maximum temperature for mid century and B2 scenario of end century will be higher than baseline period from January to June except January month of mid century where it will be lowere by $0.4^{\circ} \mathrm{C}$ than baseline maximum temperature of $18.7^{\circ} \mathrm{C}$ (Table 1). After June onwards, from July to December there would be decrease in maximum temperature from baseline period. Higher maximum temperature than baseline period would be observed till September and August in A1B and A2 scenario of end century, in later months it would decrease than baseline till end of the year. May will be the hottest month having highest mean maximum temperature in all the scenarios.

Rupakumar et al (2006) projected a temperature rise of 2.9-4. $1{ }^{\circ} \mathrm{C}$ for India under B2 and A2 scenario in 2080's relative to 1970's, whereas Krishankumar et al (2011) reported warming of 3.5-4. $3^{\circ} \mathrm{C}$ over the same period for A1B scenario. Chaturvedi et al (2012) also predicted the warming in India by $1.7-2.0^{\circ} \mathrm{C}$ by 2030 's and $3.3-4.8^{\circ} \mathrm{C}$ by 2080 's relative to pre-industrial periods.

\section{Changes in minimum temperature}

The PRECIS model projections indicate that the annual minimum temperature may increase by $4.9^{\circ} \mathrm{C}$ in the mid century. Also, a warming trend was observed towards the end of century (2071-2100) under different scenarios (Table 2 ). At the end of century, annual minimumtemperature may be higher by $7.4,6.5^{\circ} \mathrm{C}$ and $5.0^{\circ} \mathrm{C}$ under the $\mathrm{A} 1 \mathrm{~B}, \mathrm{~A} 2$ and $\mathrm{B} 2$ scenarios, respectively as compared to the baseline period $\left(16.0^{\circ} \mathrm{C}\right)$

Increase in minimum temperature will be higher for the rabi season as compared to the kharif season. The rate of increase would also vary with the time of century. For example, under A1B of mid century and under A1B, A2 and $\mathrm{B} 2$ scenario of the end century, the increase in minimum temperature would be $7.4,10.1,9.0$ and $7.6^{\circ} \mathrm{C}$, respectively from baseline minimum temperature of $22.6^{\circ} \mathrm{C}$ during kharif season; and $2.3,4.7,4.1$ and $2.3^{\circ} \mathrm{C}$, respectively as compared to baseline minimum temperature of $9.3^{\circ} \mathrm{C}$ during the $\mathrm{rabi}$ season.

January would be the coolest month in all the scenarios having lowest minimum temperature $\left(0.7\right.$ to $\left.3.2^{\circ} \mathrm{C}\right)$ (Table 2). Minimum temperature will be higher than baseline in all the months of the year except January,February and December for the A1B scenario of mid century. The minimum temperature may be lowered by $4.0,0.3$ and $2.8^{\circ} \mathrm{C}$ than the baseline temperature of $5.22,6.87$ and $5.99^{\circ} \mathrm{C}$, respectively during month of January, February and December. 
Table 3 : Changes in rainfall $(\mathrm{mm})$ for the mid and end century for different scenarios and their deviation from baseline period

\begin{tabular}{|c|c|c|c|c|c|}
\hline \multirow[t]{2}{*}{$\begin{array}{l}\text { Month/ } \\
\text { Season }\end{array}$} & \multirow[t]{2}{*}{$\begin{array}{c}\text { Baseline } \\
(1971-1990)\end{array}$} & \multirow{2}{*}{$\begin{array}{c}\text { Mid century } \\
(2021-2050) \\
\text { A1B }\end{array}$} & \multicolumn{3}{|c|}{$\begin{array}{l}\text { End century } \\
(2071-2100)\end{array}$} \\
\hline & & & A1B & $\mathrm{A} 2$ & B2 \\
\hline January & 25 & $22(-3)^{*}$ & $21(-4)$ & $7(-18)$ & $12(-13)$ \\
\hline February & 30 & $13(-17)$ & $19(-11)$ & $7(-23)$ & $8(-22)$ \\
\hline March & 26 & $19(-7)$ & $23(-3)$ & $11(-15)$ & $20(-6)$ \\
\hline April & 19 & $22(-3)$ & $19(0)$ & $10(-9)$ & $15(-4)$ \\
\hline May & 23 & $24(+1)$ & $22(-1)$ & $26(+3)$ & $26(+3)$ \\
\hline June & 66 & $123(+57)$ & $124(+58)$ & $185(+119)$ & $188(+122)$ \\
\hline July & 229 & $281(+52)$ & $358(+128)$ & $255(+26)$ & $279(+50)$ \\
\hline August & 186 & $245(+59)$ & $296(+110)$ & $228(+42)$ & $216(+30)$ \\
\hline September & 103 & $162(+59)$ & $155(+52)$ & $214(+111)$ & $223(+120)$ \\
\hline October & 7 & $77(+70)$ & $73(+66)$ & $86(+79)$ & $103(+96)$ \\
\hline November & 10 & $59(+49)$ & $62(+52)$ & $25(+15)$ & $27(+17)$ \\
\hline December & 18 & $29(+11)$ & $33(+15)$ & $10(-8)$ & $15(-3)$ \\
\hline Kharif & 614 & $912(+298)$ & $1027(+413)$ & $995(+381)$ & $1035(+421)$ \\
\hline Rabi & 128 & $165(+37)$ & $172(+44)$ & $72(-56)$ & $98(-30)$ \\
\hline Annual & 741 & $1075(+334)^{*}$ & $1204(+463)$ & $1066(+325)$ & $1131(+390)$ \\
\hline
\end{tabular}

* Figures in parenthesis indicate the change in mm rainfall from the baseline period

At the end of century (2071-2100), the minimum temperature under the three scenarios i.e. $\mathrm{A} 1 \mathrm{~B}, \mathrm{~A} 2$ and $\mathrm{B} 2$ may get lowered than the baseline minimum temperature by the 2.0,2.9 and $4.5^{\circ} \mathrm{C}$, respectively in the month of January and by $0.8,2.9$ and $4.3{ }^{\circ} \mathrm{C}$, respectively in the month of December. The remaining months from February to November may experience higher minimum temperature during the end of the century. The rise in temperature would be higher in the end century than mid century.

\section{Changes in rainfall}

The rainfall projections of $21^{\text {st }}$ century by PRECIS model indicate that the annual rainfall will increase by 333 $\mathrm{mm}$ as compared to the baseline rainfall of $741 \mathrm{~mm}$ in the mid century (Table 3). At the end of century, annual rainfall will be higher from the baseline period by $463 \mathrm{mmin}$ the A1B scenario, $325 \mathrm{~mm}$ in the $\mathrm{A} 2$ scenario and $390 \mathrm{~mm}$ in the $\mathrm{B} 2$ scenario.Increase in rainfall will be higher for the kharif season as compared to the rabi season.During the baseline period, rainfall was $614 \mathrm{~mm}$ during kharif and $128 \mathrm{~mm}$ during rabi season, which would increase respectively by $298 \mathrm{~mm}$ $(32.6 \%)$ and $37 \mathrm{~mm}(22.7 \%)$ by the mid century. The kharif season rainfall for the end century may be increased by 413 $\mathrm{mm}(40.2 \%), 381 \mathrm{~mm}(38.3 \%), 421 \mathrm{~mm}(40.7 \%)$ for A1B, $\mathrm{A} 2$ and $\mathrm{B} 2$ scenarios, respectively. The A1B scenario predict the rise in rainfall by $44 \mathrm{~mm}(25.9 \%)$ whereas A2 and B2 scenario predict decrease in rainfall by $56 \mathrm{~mm}(78.3 \%)$ and $30 \mathrm{~mm}(30.8 \%)$, respectively during the rabi season. The rainfall may be reduced than the baseline upto the month of April, after which it is projected to increase under all the scenarios (Table 3). Highest amount of rainfall is predicted for the month of July.

Rajendran and Kitoh (2008) also projected high rainfall events by the end of century. The trends of heavy (Palmer and Raisanen, 2002; Goswami et al, 2006) or in some places reduced precipitation (Kitoh et al, 2008) have also been observed in some other studies.Precipitation is projected to increase from 4 to $5 \%$ by 2030's and 6 to 14 $\%$ towards end of century (2080's) (Chaturvedi et al,2012).

\section{CONCLUSION}

The PRECIS model projections indicate that the maximum and minimum temperature would increase under A1B, A2 and B2 scenarios by mid and end of $21^{\text {st }}$ century. By the mid and end of $21^{\text {st }}$ century projections reveal an increase in the incidence of extreme of high (in the months of March, April, May and June) and low (in the months of December and January) temperature events thereby indicating increase in heat wave and frost conditions in crops. Higher rainfall 
as compared to baseline is likely to be experienced during the mid and end of the $21^{\text {st }}$ century. However, uneven distribution of the rainfall may be projected.

\section{REFERENCES}

Chaturvedi R K, Joshi K, Jayaraman M, Bala Gand Ravindranath N H(2012). Multimodel climate change projections for India under representative concentration pathways. Curr. Sci. 103 (7): 1-12.

Christensen J H, Hewitson B, Busuioc A, Chen A, Gao X, Held I, Jones R, Kolli R K, Kwon W T, Laprise R, Magaña RuedaV, MearnsL, Menéndez C G, Räisänen J, RinkeA, Sarr A and Whetton P (2007). Regional Climate Projections. In: Climate Change 2007: The Physical Science Basis. Contribution of Working Group I to the Fourth Assessment Report of the Intergovernmental Panel on ClimateChange [Solomon S, Qin D, Manning M, Chen Z, Marquis M, Averyt K B, Tignor Mand Miller H L (eds.)]. Cambridge University Press, Cambridge, United Kingdom and New York, NY, USA.

Dash S K and Hunt J C R (2007). Variability of climate change in India. Curr. Sci. 93(6): 782-88.

Dash S K, Jenamani R K, Kalsi S R and Panda S K(2007). Some evidence of climate change in twentieth century India. Climatic Change85: 299-321.

Goswami B N, Venugopal V, Sengupta D, Madhusoodanan M $\mathrm{S}$, and Xavier P K(2006) Increasing trend of extreme rain events over India in a warming environment. Sci. 314: $1442-45$

IPCC(2007). Climate change: the physical science basis contribtion of working group I to the fourth assessment report of intergovernmental panel on climate change (eds Solomon S, Qin D, manning M)

Islam A and Sikka A K (2010). Climate change and water resources in India: Impact assessment and adaptation strategies. In "Natural and anthropogenic disastersVulnerability, preparedness and mitigation" (Jha M K ed.), pp. 386-413. Capital Publishing Company, New Delhi and Springer, The Netherlands.

Kitoh A, Yatagai A and Alpert P (2008). First super-highresolution model projection that the ancient fertile crescent will disappear in this country. Hydrol. Res. Lat. 2: $1-4$.
Krishanakumar S K, Patwardhan A, Kulkarni K, Kamala K, Koteswara R and Jones R (2011). Simulated projections for summer monsoon climate over India by a high resolution regional climate model (PRECIS). Curr. Sci.101:312-25.

McCarthy J J, Canziani O F, Leary NA, Dokken D J and White K S(eds) (2001). Impacts, adaptation and vulnerability. In Climate Change 2001-Contribution ofWorking Group III to Third Assessment Report of Intergovernmental Panel on Climate Change, IPCC IIIAssessment Report, Cambridge University Press, Cambridge, UK.

Meehl GA, Stocker T F, Collins W D, Friedlingstein P, Gaye A T, Gregory J M, Kitoh A, Knutti R, Murphy J M, Noda A, Raper S C B, Watterson I G, Weaver A J and Zhao Z C (2007). Global Climate Projections. In: Climate Change 2007: The Physical Science Basis. Contribution of Working Group I to the Fourth Assessment Report of the Intergovernmental Panel on Climate Change [Solomon S, Qin D, Manning M, Chen Z, Marquis M, Averyt K B, Tignor M and MillerH L(eds)]. Cambridge UniversityPress. Cambridge, United Kingdom and New York, NY, USA.

Palmer T N and Raisanen J (2002). Quantifying the risk of extreme seasonal precipitation events in changing climate. Nature 415: 512-14.

Rajendran K and Kitoh A(2008). Indian summer monsoon in future climate projection by a super high resolution global model. Curr. Sci. 95 (11): 1560-69.

Recosky D C, Hatfield J L and Sass R L (2000). Agricultural contribution to green house gas emission. In: Reddy K R and Hodges HF (eds) Climate change and global crop productivity. Pp 37-55. Mississippi State University, USA.

Rozenweig Cand HillelD(1998).Agricultural emission of green house gases. In: Climate change and global harvest. Potential impacts of greenhouse effect on agriculture. Oxford University Press, New York, pp 38-100.

Rupakumar, SahaiAK, Kumar KK, Patwardhan S K, Mishra P K, Revadekar J V, Kamala K and Pant G B (2006) High resolution climate change scenarios for India for the $21^{\text {st }}$ cemtury. Curr Sci. 90(3): 334-45. 